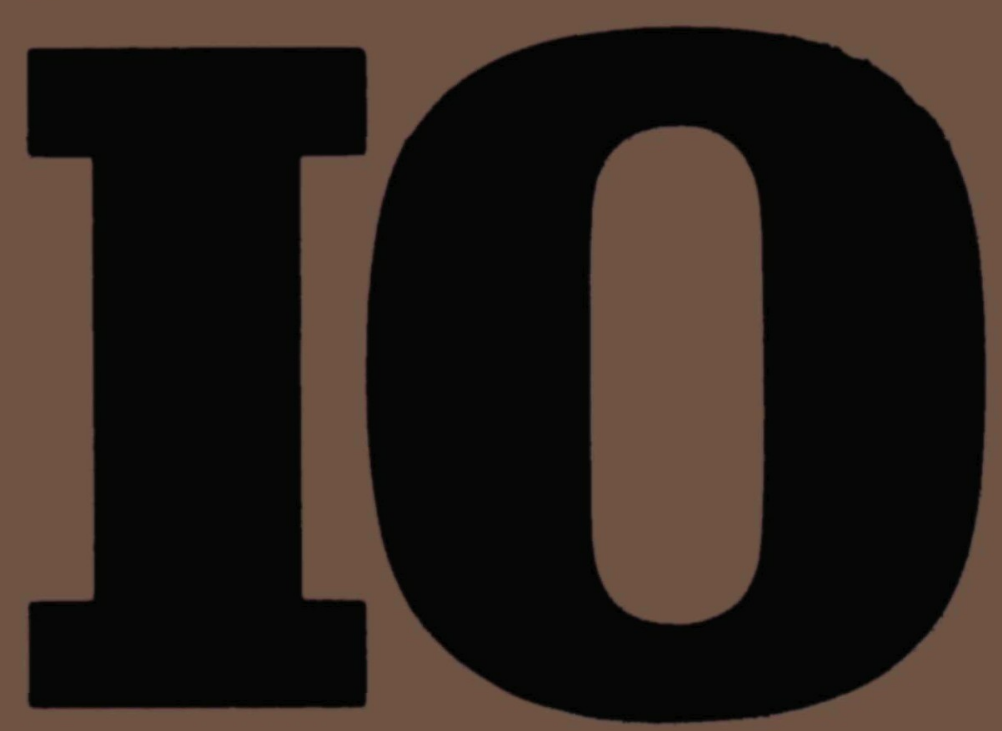

\title{
International Onganization
}

\author{
Lisa L. Martin \\ Interests, Power, and Multilateralism \\ Frederick W. Mayer \\ Managing Domestic Differences in Negotiations \\ John S. Duffield \\ NATO Force Levels and Regime Analysis \\ Ellis S. Krauss and Simon Reich \\ U.S. Policy and International Competition \\ Vicki L. Golich
}

Collaboration in the Commercial Aircraft Industry 


\section{EDITORIAL BOARD}

John Gerard Ruggie, Chairperson

\author{
David A. Baldwin \\ Robert H. Bates \\ Thomas J. Biersteker \\ Barry Buzan \\ Benjamin J. Cohen \\ Peter F. Cowhey \\ Jack Donnelly \\ Jeffry Frieden \\ Judith L. Goldstein \\ Peter Gourevitch
}

\author{
Joseph M. Grieco \\ Ernst Haas \\ Christer Jönsson \\ Miles Kahler \\ Peter Katzenstein \\ Robert O. Keohane \\ Stephen Kobrin \\ Friedrich V. Kratochwil \\ David A. Lake \\ Charles S. Maier
}

\author{
Timothy J. McKeown \\ Helen V. Milner \\ Ronald Rogowski \\ Duncan Snidal \\ Jack Snyder \\ Janice Stein \\ Beth V. Yarbrough \\ Oran R. Young \\ Mark W. Zacher
}

Editor: John S. Odell

Managing editor: Candyce Kornblum Anger

Review editors: Janice Stein

Beth V. Yarbrough

INTERNATIONAL ORGANIZATION invites the submission of manuscripts on all aspects of world politics and international political economy. Abstracts, manuscripts, and footnotes should be double-spaced. Footnotes should be numbered consecutively and placed at the end of the manuscript. Submit three copies (printed on one side of the page only), along with a statement of each author's affiliation, to the Editor, International Organization, Center for International Studies, University of Southern California, Los Angeles, CA 90089-0035. Authors may expect a decision within two months of the Editor's receipt of a manuscript.

Statements and opinions expressed in International Orga. nization are the responsibility of the authors alone and do not imply the endorsement of the Board of Editors, the Board of Trustees of the World Peace Foundation, the University of Southern California, or The MIT Press.
Intermational Organization (ISSN 0020-8183) is published quarterly--Winter, Spring, Summer, and Autumn-by The MIT Press, 55 Hayward Street, Cambridge, MA 02142 .

Subscriptions and business correspondence: For inquiries concerning subscriptions, write to MIT Press Journals, 55 Hayward Street, Cambridge, MA 02142 , or telephone the Circulation Dept. at (617) 253-2889. Yearly subscription rates for students are $\$ 20$; for other individual subscribers, $\$ 35$; and for institutions, \$80. Subscribers outside the United States should add $\$ 14$ for postage and handling. Canadian subscribers also add $7 \%$ GST. Prices are subject to change without notice. To be honored free of charge, claims for missing copies must be made immediately upon receipt of the next published issue. Postmaster: send address changes to International Organization, 55 Hayward Street, Cambridge, MA 02142. Second Class postage is paid at Boston, $M A$, and at additional mailing offices.
Advertising: Please write to Advertising Manager, MIT Press Journals, 55 Hayward Street, Cambridge, MA 02142 USA, or telephone (617) 253-2886.

Rights and permissions: All inquiries concerning rights and permissions should be sent to Subsidiary Rights Manager, attention: International Organization, MIT Press Journals, 55 Hayward Street, Cambridge, MA 02142 .

Permission to photocopy articles for internal or personal use or the internal or personal use of specific clients is granted by the World Peace Foundation and the Massachusetts Institute of Technology for libraries and other users registered with the Copyright Clearance Center (CCC), provided that the fee of $\$ 3.00$ per copy is paid directly to CCC, 27 Congress Street, Salem, MA 01970. The fee code for users of the Transactional Reporting Ser. vice is $0020-8183 / 92 \$ 3.00$. For those organizations that have been granted a photocopy license with $\mathrm{CCC}$, a separate system of payment has been arranged. 


\section{International Organization \\ Volume 46, Number 4, Autumn 1992}

\section{Articles}

Interests, power, and multilateralism Lisa L. Martin 765

Managing domestic differences in international negotiations: the strategic use of internal side-payments Frederick W. Mayer

International regimes and alliance behavior: explaining NATO 819 conventional force levels John S. Duffield

Ideology, interests, and the American executive: toward a theory of foreign competition and manufacturing trade policy Ellis S. Krauss and Simon Reich

From competition to collaboration: the challenge of commercial-class aircraft manufacturing Vicki L. Golich 


\section{Contributors}

John S. Duffield is Assistant Professor of Government and Foreign Affairs at the University of Virginia, Charlottesville.

Vicki L. Golich is Assistant Professor of Political Science in the College of Arts and Sciences, California State University, San Marcos, California, and Faculty Associate of the Center for Research in Conflict and Negotiation in the Smeal College of Business Administration at the Pennsylvania State University, University Park.

Ellis S. Krauss is Professor of Political Science at the University of Pittsburgh, Pennsylvania.

Lisa L. Martin is Associate Professor of Government at Harvard University.

Frederick W. Mayer is Assistant Professor of Public Policy Studies at The Institute of Policy Sciences and Public Affairs, Duke University, Durham, North Carolina.

Simon Reich is Associate Professor at the Graduate School of Public and International Affairs, University of Pittsburgh, Pennsylvania. 


\section{Abstracts}

\section{Interests, power, and multilateralism}

by Lisa L. Martin

Multilateralism characterizes, to varying degrees, patterns of interaction among states and the formal organizations they construct. The utility of multilateral norms or organizations varies with the type of cooperation problem states confront. Thus, the functional logic of international cooperation leads to hypotheses about the conditions under which the institution of multilateralism may be a feasible and efficient solution, as in coordination problems, and those under which it will not, as in collaboration problems. Within these constraints, powerful states choose institutions that will serve their interests, with multilateral arrangements becoming more attractive as the future is valued more highly. Multilateral institutions should be stable in circumstances of changing distributions of power, relative to more hierarchical institutions. The vulnerability of patterns of international cooperation to various exogenous changes depends on the type of strategic interaction underlying state behavior.

\section{Managing domestic differences in international negotiations: the strategic use of internal side-payments}

by Frederick W. Mayer

When nations negotiate, often the toughest bargaining is not between nations but within them. The reason is simple: proposed international agreements, no matter how much in the "national interest," inevitably have differential effects on factional concerns, threatening to make winners of some and losers of others. Potential losers often have the power to prevent agreements not to their liking, thereby limiting what is possible in international negotiations. This article uses a negotiation analytic framework to analyze the consequences of such limits. It argues that limits need not be a liability for a divided country - under some circumstances they may provide a bargaining advantage—and demonstrates circumstances under which intracountry differences are desirable and undesirable from a national perspective. More specifically, the article shows that the effect of domestic differences on international negotiations depends on the configuration of domestic interests, on the nature of domestic political processes, and on characteristics of the international bargain. It then explores a particular dimension of the domestic process: the ability to link issues which allow factions to make internal side-payments. It demonstrates that internal issue linkage can have profound effects on 
the external bargain and explores the strategic implications of side-payments for those who would manage domestic differences in international negotiations.

\section{International regimes and alliance behavior: explaining NATO conventional force levels}

by John S. Duffield

With the end of the cold war, the military posture of the North Atlantic Treaty Organization (NATO) has entered a period of profound change. Prior to the recent dramatic political events in Europe, however, NATO conventional force levels in the Central Region had been remarkably stable for some three decades. This article seeks to explain this record of stability in terms of three widely used theories of international relations. It argues that balance-of-power theory and public goods theory cannot alone provide a satisfactory account. Rather, these traditional approaches for understanding alliance behavior must be supplemented by regime theory, which emphasizes the constraining effects of enduring institutional factors even in the face of structural change. Specifically, it shows how an international regime has influenced the provision of conventional forces in the Central Region by alliance members. More generally, this analysis seeks to contribute to the literature on international regimes in three ways. First, it demonstrates that regimes do matter by providing an example of their importance for explaining state behavior and international outcomes. Second, it extends regime theory to relations among military allies. Third, it elaborates a comprehensive model for understanding why states actually comply with regime injunctions. The model stresses both the ways in which regimes effectively modify the international environment within which states operate, altering the costs and benefits associated with different courses of action, and the ways in which participating states may internalize regime norms and rules, thereby making compliance increasingly automatic.

\section{Ideology, interests, and the American executive: toward a theory of foreign competition and manufacturing trade policy}

by Ellis Krauss and Simon Reich

Faced with a formidable competitiveness problem, the American government chief executive appeared to offer a series of ad hoc responses in the 1980s. Contrarily, this article suggests that executive responses to foreign economic challenges follow a predictable pattern. Pointing to the interactive effects of ideology and interest, this article argues that both the degree and type of executive response, be it in the form of market-opening strategies, of temporary or permanent forms of protectionism, or of adopting a laissez-faire approach, can be predicted based on two factors: whether a sector is characterized as "high tech" and whether it is considered to be competitive. A major implication of this argument is that the U.S. chief executive has used trade policy as a surrogate for industrial policy; but in so doing, the strategic considerations associated with industrial policies have been bypassed. The major effect is that the executive fails to intervene only in the realm of an "infant industry" policy-the area most likely to generate a dynamic economy. The product of this combiantion of protectionist policies is a stagnant economy that we term "compromise protectionism." 
From competition to collaboration: the challenge of commercial-class aircraft manufacturing

by Vicki L. Golich

Sectoral analyses reveal an emerging tension between a global market and an anarchic political system and oblige scholars to examine the dynamic and reciprocal relationship between states and markets. This analysis of commercial-class aircraft manufacturing, a strategic industry, demonstrates how corporate behavior affects political choices and vice versa. It suggests that corporate and political policymaking is a messy process: first, policymakers must respond to multiple and often conflicting demands, from both domestic and international constituencies; second, they are influenced by a number of variables, including ideology, interest group activity, consequences of previous policies, perceptions about their state's position in the international system, and available knowledge about how to realize specific goals. Sets of competing variables which act as centripetal and centrifugal forces are identified and analyzed in terms of how they have impelled corporations to seek transnational production arrangements. Three prototypical structures of international production are delineated, and the potential consequences for states and corporations participating in each model are discussed. The key objectives of the article are to encourage the use of multivariate analyses to explain change in the international system and to provoke further debate about the appropriate policies to pursue to achieve global economic competitiveness across a number of industry sectors. 